\title{
Reviewing Fire, Climate, Deer, and Foundation Species as Drivers of Historically Open Oak and Pine Forests and Transition to Closed Forests
}

\author{
Brice B. Hanberry ${ }^{1 *}$, Marc D. Abrams ${ }^{2}$, Mary A. Arthur ${ }^{3}$ and J. Morgan Varner \\ ${ }^{1}$ USDA Forest Service, Rocky Mountain Research Station, Rapid City, SD, United States, ${ }^{2}$ Department of Ecosystem \\ Science and Management, Pennsylvania State University, University Park, PA, United States, ${ }^{3}$ Department of Forestry and \\ Natural Resources, University of Kentucky, Lexington, KY, United States, ${ }^{4}$ Tall Timbers Research Station, Tallahassee, FL, \\ United States
}

\section{OPEN ACCESS}

Edited by:

Warren E. Heilman, United States Forest Service (USDA),

United States

Reviewed by:

Panayiotis G. Dimitrakopoulos, University of the Aegean, Greece

Joseph J. O'Brien,

Forest Service Southern Research

Station (USDA), United States

${ }^{*}$ Correspondence:

Brice B. Hanberry

brice.hanberry@usda.gov

Specialty section: This article was submitted to

Fire and Forests,

a section of the journa

Frontiers in Forests and Global

Change

Received: 14 October 2019 Accepted: 14 April 2020

Published: 12 May 2020

Citation:

Hanberry BB, Abrams MD, Arthur MA and Varner JM (2020)

Reviewing Fire, Climate, Deer, and Foundation Species as Drivers of Historically Open Oak and Pine

Forests and Transition to Closed

Forests.

Front. For. Glob. Change 3:56 doi: 10.3389/ffgc.2020.00056
Historically open oak and pine savannas and woodlands have transitioned to closed forests comprised of increased numbers of tree species throughout the eastern United States. We reviewed evidence for and against a suite of previously postulated drivers of forest transition focused on (1) change in fire regimes, (2) increased precipitation, (3) increased white-tailed deer densities, and (4) loss of American chestnut. We found that fire and fire exclusion provide a parsimonious mechanism for historical dominance by open forests of fire-tolerant oak and/or pine species and subsequent transition to closed forests with fire-sensitive tree species that fill the vertical profile. Based on statistical tests, increased precipitation during the past century was within historical ranges and thus fails to provide an explanation for forest change; additionally, precipitation variability is incongruent with tree traits (i.e., both drought-tolerant and drought-intolerant species have increased and decreased) and patterns of tree establishment. Similarly, current deer densities fail to provide a statistical relationship to explain tree densities at regional scales, species trends are unrelated to deer browse preferences, and both historically open forests and contemporary closed forests contained high deer densities. Functional extinction of the American chestnut had localized impacts but chestnut was not abundant compared to oak or widespread enough in distribution to match forest transitions throughout the eastern United States. Although Euro-American settlement affected many processes, not all changes were consistent enough to cause transitions in forest composition and structure that generally trailed westward expansion by Euro-American settlers. Evidence about these drivers continues to mount and we recognize the need for further research and continual re-evaluation of drivers of historical forests and forest change due to importance for understanding and management of these ecosystems.

Keywords: American chestnut, fire exclusion, land use change, mesophication, precipitation, white-tailed deer 


\section{INTRODUCTION}

During the last century or more, open upland oak (Quercus) and pine (Pinus) savannas and woodlands across eastern North America (Figure 1) have transitioned to dense closed forests comprised of diverse tree species (e.g., Nowacki and Abrams, 2008; Fralish and McArdle, 2009; Hanberry and Nowacki, 2016; Hanberry and Abrams, 2018; Hanberry et al., 2018a,b). Open forests of savannas and woodlands characteristically contained a simple bilayer structure of overstory trees and a diverse herbaceous groundlayer (Figure 2A; Nowacki and Abrams, 2008; Van Auken, 2009; Hanberry and Abrams, 2018). Trees now fill the vertical profile to the canopy, outcompeting herbaceous vegetation, and larger diameter trees have doubled or tripled in number (Figure 2B; Hanberry and Abrams, 2018; Hanberry et al., 2018b). Furthermore, trees have encroached into adjacent grassland openings and larger expanses of grassland and shrubland ecosystems (e.g., in the central United States; Gleason, 1922; McComb and Loomis, 1944; Abrams, 1986; Briggs et al., 2005; Hanberry and Hansen, 2015).

As forests have become more dense, composition also has shifted from fire-tolerant oak and pine species to a mixture of eastern tree species (or planted pine species, which are fireadapted; Abrams, 1992; Nowacki and Abrams, 2008; Hanberry and Abrams, 2018; Hanberry et al., 2018a,b). In the central eastern US, primarily white oak (Quercus alba) with different combinations of black oak (Q. velutina), post oak (Q. stellata), rock chestnut oak (Q. montana), northern red oak (Q. rubra), bur oak (Q. macrocarpa), blackjack oak (Q. marilandica), and southern red oak ( $Q$. falcata) were dominant species comprising about 55\% of all trees (Figure 1; Hanberry and Nowacki, 2016). The density of oak has decreased relative to other broadleaf tree species to only about $25 \%$ of all trees in the central eastern US as forests have become dense (e.g., Hanberry and Abrams, 2018). In forests of the southeastern US, longleaf pine (Pinus palustris) and open oak and shortleaf pine ( $P$. echinata) have decreased from $75 \%$ of all trees; longleaf pine in the Coastal Plain and shortleaf pine in the northern Southeast are now only $2 \%$ to $3 \%$ of all trees (Hanberry and Nowacki, 2016; Hanberry et al., 2018c, 2019).

There are several suggested mechanisms for widespread ecosystem transitions. The absence of frequent surface fires has been offered to explain loss of oaks and pines and relative success of maples (Acer) and other fire-sensitive tree species (Abrams, 1990; Gilliam and Platt, 1999; Nowacki and Abrams, 2008). The concept of mesophication (Nowacki and Abrams, 2008) conveys the measurable state transition from fire-tolerant oak and pine species, and their associated open forest structure, to fire-sensitive species of dense forests as surface fire is excluded and forests become more resistant to surface fires, due in part to replacement of herbaceous vegetation (i.e., fine fuels for frequent, low severity fire) by increased number of trees with poorly flammable litter (Kreye et al., 2013; Dickinson et al., 2016; Babl et al., 2020). Conversely, the climate hypothesis (e.g., McCarthy et al., 2001; Pederson et al., 2015) posits that dry climate in the past favored drought-tolerant oak and pine species and increased tree mortality, resulting in open forests, while recent pluvials, or increases in precipitation, have allowed drought-sensitive species to become competitive and establish at great tree densities. The "multiple interacting ecosystem drivers hypothesis" (McEwan et al., 2011) proposes that ecosystems changed due to increased precipitation combined with changing fire regimes and land use, loss of the foundation tree species American chestnut (Castanea dentata), increased native white-tailed deer (Odocoileus virginianus) densities, and other fluctuating wildlife populations (McEwan et al., 2011).

Transitions from historical forests before Euro-American settlement to contemporary forests coincided with numerous unprecedented changes caused by settlement, but not all changes in ecological processes are consistent with patterns in forest transitions (see Figure 3 for Euro-American settlement, which divided historical and contemporary forests, albeit with a time lag). Here, we reviewed primary components of forest transition hypotheses, covering fire and fire exclusion, drought and increased precipitation, change in land use, reduced and then recovered deer populations, and loss of American chestnut, by provided supporting and contradicting evidence based on expected patterns and realized outcomes. Thorough investigation of mechanisms for ecosystem change (e.g., McEwan et al., 2011; Kreye et al., 2013; Nowacki and Abrams, 2015; Pederson et al., 2015) is key to understanding ecosystems, ecological processes, trajectories, and likely effectiveness and consequences of current and future management of forests in the eastern United States and elsewhere. Although this review contributes updated information to the exchange among researchers across disciplines, repeated evaluation of drivers of historical forests and forest change will be necessary as evidence becomes available.

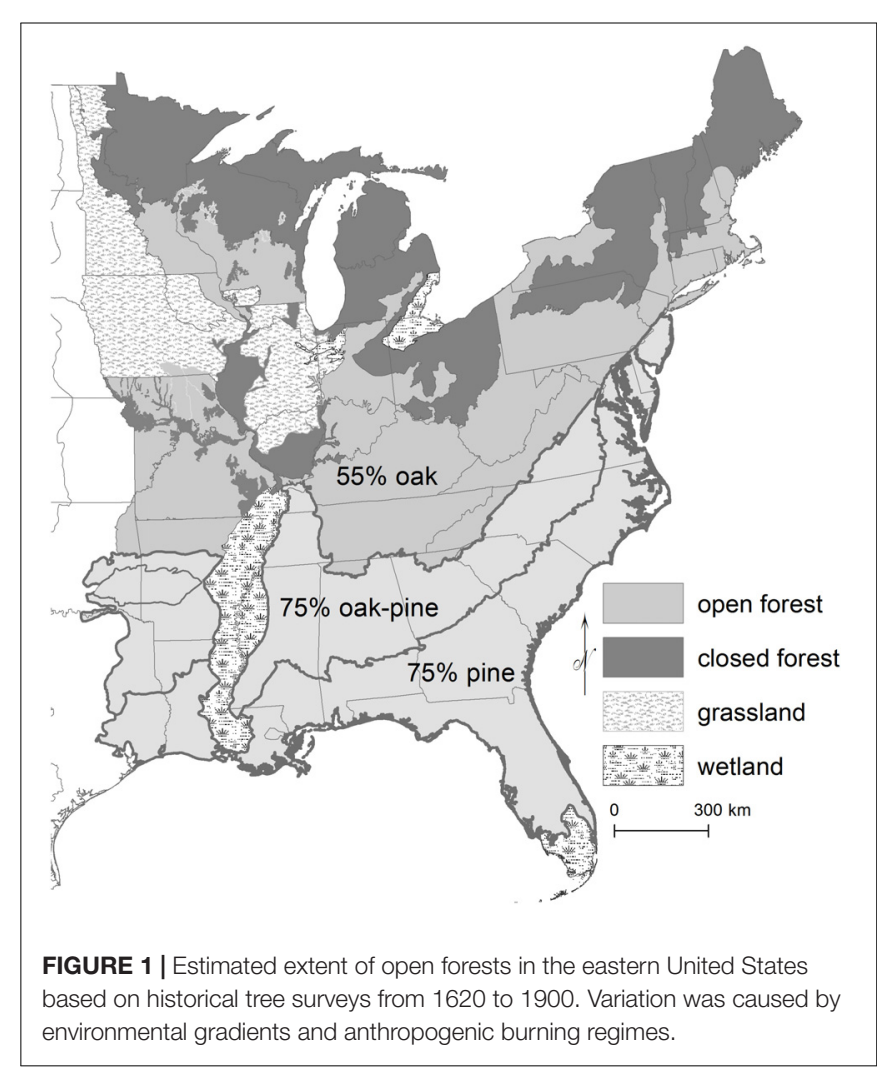



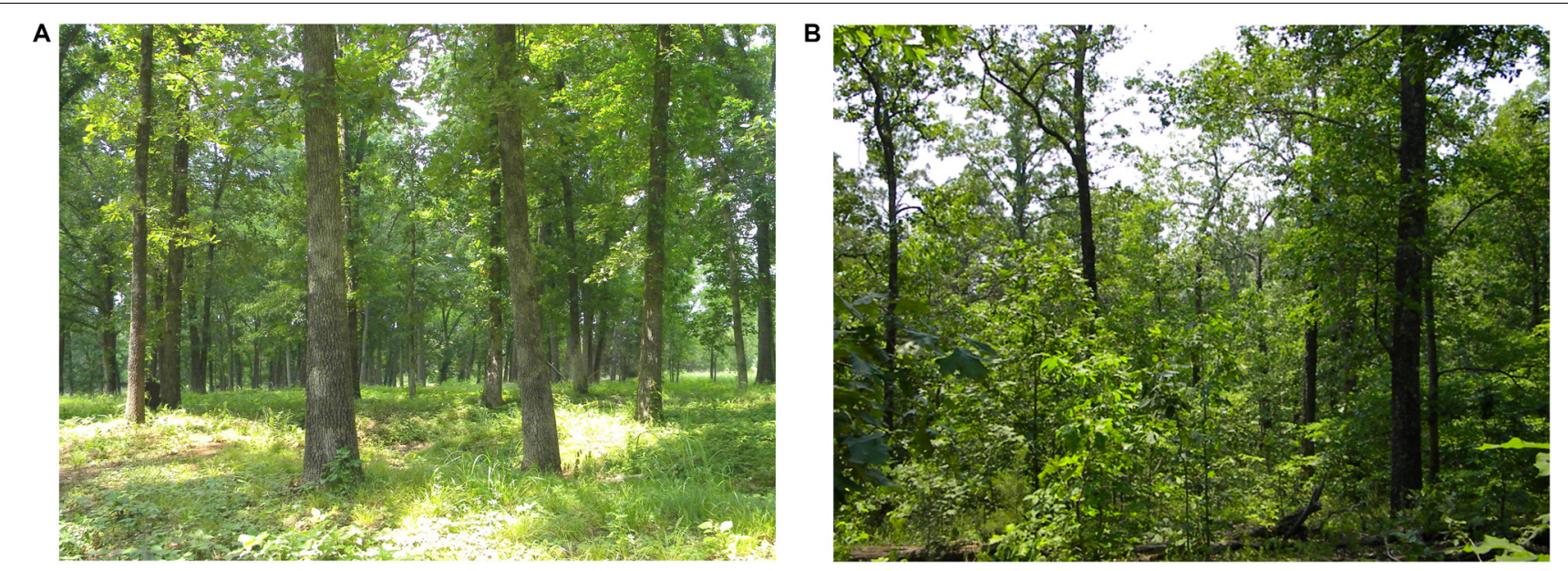

FIGURE 2 | Characteristic structure of open forests (panel A), which have an overstory tree layer and herbaceous layer, and closed forests (B), which have trees throughout the vertical profile to the canopy, replacing the herbaceous layer. Photos from stands in Missouri treated by prescribed burns (A) or without treatment (B), courtesy of C. Kinkead.

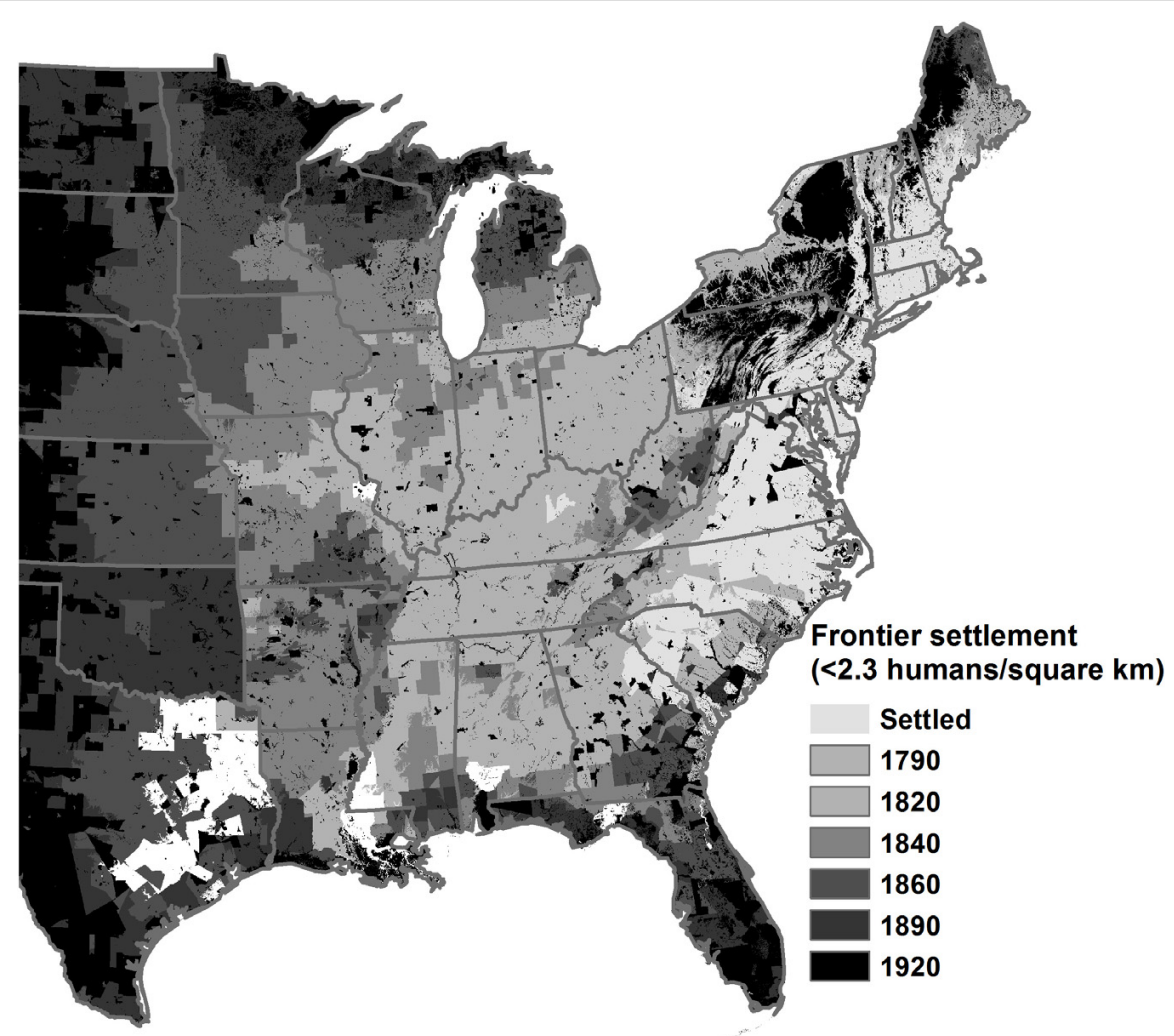

FIGURE 3 | Frontiers ( $<2.3$ humans/ $\mathrm{km}^{2}$ ) of Euro-American settlement where years represent the area that increased from a frontier to greater human densities (modified based on Fang and Jawitz, 2018). Fine scale variation results in remote locations even after increased settlement.

\section{FIRE AND FIRE EXCLUSION}

\section{Description}

Evidence continues to accumulate that frequent surface fires occurred historically every 2 to 25 years in most of the eastern United States, based on studies of fire scars, charcoal, contemporaneous accounts, and dominance by fire-tolerant trees ranging back 12,000 years, until fire exclusion during the first half of the 1900s (Gleason, 1922; Bromley, 1935; Day, 1953; Delcourt and Delcourt, 1987; Wade et al., 2000; Parshall and Foster, 2002; 
Williams, 2005; Stambaugh et al., 2015, 2018; Hanberry and Nowacki, 2016; Abadir et al., 2019; Abrams and Nowacki, 2019; Hutchinson et al., 2019; Marschall et al., 2019). The eastern United States has areas of great lightning strike frequency and in pre-industrial societies, fire was the primary tool to clear forests for shifting agricultural cultivation as well as to open forests for plants and associated game animals and for ease of movement (Fuller et al., 1998; Brown, 2000; Brose et al., 2001; Whitney and DeCant, 2003; Williams, 2005; Bowman et al., 2013; Varner et al., 2016a). Fire regimes are complex and vary depending on fuel availability and weather (i.e., necessary moisture to grow fine fuels followed by dry intervals to allow ignition; Guyette et al., 2012).

\section{Mechanism}

The fire hypothesis suggests that dominance by fire-tolerant trees and reduced tree densities occurred due to frequent low severity fire and that transitions in species composition and structure have occurred due to fire exclusion (both passive exclusion via fragmentation by roads and other land uses and vegetation composition and structure that resist fire spread and active via fire suppression and termination of deliberate ignitions for forest management). These mechanisms led to changes from species with traits that promote and tolerate frequent surface fire (thick bark, rapid self-pruning, flammable litter, bud protection) to those that lack fire-surviving traits and diminish fire (thin bark, poor flammability of litter; Abrams, 1990; Nowacki and Abrams, 2008; Mitchell et al., 2009; Varner et al., 2016b). Low to moderate intensity surface fire can kill small diameter woody vegetation, limit tree density, and promote the cover and diversity of herbaceous vegetation in the groundlayer. Herbaceous vegetation provides continuous fine fuels that ignite easily and spread more readily than litter, shrubs, or coarse woody fuels. Historically dominant and fire-resistant oaks and pines supplemented this community flammability via their litterfall (Mitchell et al., 2009; Dickinson et al., 2016; Kreye et al., 2018; Babl et al., 2020). We expect that for historical fire regimes and fire exclusion to be a driver, historically dominant fire-tolerant oaks and pines should decrease in composition and fire-sensitive species should increase in composition with associated increases in tree densities.

\section{Pattern}

The presence of fire explains dominance by fire-tolerant oak and pine in open forests through thousands of years of natural climate change, including the recent Medieval Warm Age and Little Ice Age (Delcourt and Delcourt, 1987; Lorimer, 2001; Hanberry and Nowacki, 2016). During the Native American depopulation period (depending on location, beginning with European contact during the 1500s), fire frequency may have varied followed by increased fire frequency during early Euro-American settlement (depending on location, 1600 s to 1800 s) before fire exclusion (Stambaugh et al., 2018; Abrams and Nowacki, 2019). Reduced populations of indigenous people do not automatically equate to less fire activity (Liebmann et al., 2016; Abrams and Nowacki, 2019). Indeed, decreased human densities and a decreased labor pool may have provided both greater safety and need for fire as a labor-saving tool. Knorr et al. (2014) found that increasing human populations reduced fire frequency through active fire suppression and vegetation fragmentation, and fires generally were not limited by ignitions. Abrams and Nowacki (2019) showed a steady amount of charcoal production in the eastern US, despite human population declines before EuroAmerican settlement.

Because oak and pine species were dominant historically and lived for centuries, a century without fire due to skipped fire cycles, in the absence of harvest and other now frequent overstory disturbances, would have allowed more oak and pine recruitment from advance oak and pine regeneration into the overstory. Overstory trees are more competitive than small diameter trees for resources and provide a control on tree regeneration. Some amount of conversion to fire-sensitive species may occur, but these species would need to disperse from fire-protected sites and then successfully compete against established trees. Indeed, Buchanan and Hart (2012) documented a great increase in oak establishment during 1720 to 1799 and during 1840 to 1920, albeit to a lesser extent than 1720 to 1799 , throughout most of the eastern US (Buchanan and Hart, 2012). Current abundance of historically transient fire-sensitive species may result in reduced intervals of 35 years without fire as a threshold now before open oak and pine forests transition to closed forests (given lack of local edaphic factors or other management that may favor oak and pine savannas; Fralish and McArdle, 2009).

Alternative ecosystem states of open forests and closed canopy forests both may occur in regions with moderate precipitation. Rather than water limitations on tree biomass, disturbance by fire restricts closed forests through positive feedbacks. Low to moderate severity fire removes small diameter woody vegetation, regulating tree density in the overstory and midstory and allowing dominance of herbaceous vegetation in the groundlayer. Herbaceous vegetation and limited vegetation in the midstory direct fire to spread horizontally instead of up tree crowns, which limits severity. Herbaceous vegetation provides fine fuels that ignite more readily than coarse woody fuels, increasing fire frequency. Additionally, low severity fire filters species composition, favoring fire-tolerant tree species of pines and oaks, which also contribute flammable fuels, including leaf litter (Kreye et al., 2013, 2018; Babl et al., 2020). Exposure to sun and wind promote ignition conditions by curing vegetation and spreading fire.

Conversely, closed forests act as firebreaks by disrupting continuity of fine fuels and open environmental conditions that allow fire ignition and spread. Closed forests moderate the environment, maintaining humidity and blocking sun and wind. Tree density in closed forests is sufficient to suppress flammable fine vegetation and the litter of fire-sensitive tree species often is not flammable (Kreye et al., 2013, 2018; Babl et al., 2020), and further controls herbaceous vegetation.

After extensive tree harvesting followed by fire exclusion, as occurred during Euro-American settlement, or extended fire exclusion alone, forests transitioned in state from open to closed, due to increased competition from fire-sensitive species. Fire exclusion accounts for (1) increased dominance of fire-sensitive species, (2) increased tree density, and (3) expansion of trees 
into grasslands and other non-forested ecosystems (e.g., Gleason, 1922; Varner et al., 2005; Hanberry and Abrams, 2018; Hanberry et al., 2018a). Fire exclusion also appears to generally match timing of forest transitions in the wake of Euro-American settlement (see Figure 3; e.g., Gleason, 1922; Bromley, 1935; Day, 1953; Neumann, 1985).

Closed forests have moved beyond a threshold in which simply adding fire can alter forest structure quickly. By definition, a transition from one state to another is promoted by positive feedbacks that are difficult to reverse and closed forests of firesensitive species are resistant to fire, which makes restoration challenging (Nowacki and Abrams, 2008; Alexander and Arthur, 2010; Stambaugh et al., 2015). Adding to the challenge, most overstory trees now are not oak or pine and propagules of fire-sensitive species are abundant. In the current matrix of contemporary closed forests, prescribed burns in small patches of tens to hundreds of hectares may be insufficient to favor oak and pine regeneration when there is a steady influx of seeds from adjacent land or sprouts from established invaders (Brose et al., 2013). Reversal of fire-sensitive species establishment may require multiple burns, often at greater intensity than typically applied through prescriptions, while forests under conditions protected from fire may never favor oak or pine species (Brown, 1960; Arthur et al., 2012; Brose et al., 2013; Ryan et al., 2013). Fire spread and intensity are hampered in closed forests due to humid, cool conditions with reduced wind and lack of herbaceous vegetation or flammable litter (Kreye et al., 2018). The current composition of forests along with fragmentation by roads and other fire breaks also help clarify why prescribed fires may be ineffective.

\section{Contradictory Evidence}

The argument against the fire hypothesis as the primary driving factor for ecosystem change questions whether fire alone was sufficient to maintain historical oak and pine ecosystems (McCarthy et al., 2001; McEwan et al., 2011). McEwan et al. (2011), echoed by Matlack (2013), pointed out that prescribed burns often are ineffective at restoring open oak and pine forests, as noted above, disputing the narrative that lack of fire is the key driver of increased stem density and presence of fire-sensitive species. Another principal argument against the fire hypothesis is a gap in fire history during the Native American depopulation period and before Euro-American settlement. McEwan et al. (2011) remarked on skipped fire cycles particularly during 16501800 and east of the Mississippi River. For example, McCarthy et al. (2001) found frequent fire scars during 1731-1881 from one tree in Ohio, with no antecedent fire during the previous century. McEwan et al. (2011) wrote: "Further work is needed that can (1) extend our understanding of fire history in oak forests prior to 1800 , and (2) deepen understanding of the transition from Native American to Euro-American land-use. . .what is the likelihood of an anthropogenic fire regime, sufficiently widespread, frequent and intense to limit regeneration of maples across a vast and topographically complex region, in a landscape that was largely depopulated for $>125$ year?" We cited above that some of the further work has occurred, prompting an update.

\section{DROUGHT AND INCREASED PRECIPITATION}

\section{Description}

Climate has long been used to explain plant communities, tree species distributions, and tree establishment patterns (Iverson and Prasad, 1998). Examples include the Köppen-Trewartha climate types and plant hardiness zones (Copenhaver-Parry et al., 2017; Hanberry and Fraser, 2019). McEwan et al. (2011) compared the past 500 years of both the eastern and western halves of the eastern US using tree-ring reconstructions of Palmer Drought Severity Index (PDSI; Palmer, 1965; Cook et al., 2008) and detected increased pluvials (i.e., intervals of increased precipitation based on a threshold of PDSI values $\geq 0.25$ lasting more than three years) and decreased drought since the $1870 \mathrm{~s}$.

\section{Mechanism}

Greater precipitation may result in increased tree survival and growth of drought-sensitive tree species, compared to historical dominance of drought-tolerant species, and concurrent development of closed forests (McCarthy et al., 2001; McEwan et al., 2011). Conversely, drought causes tree mortality, pushes back forest borders, and favors drought-tolerant species (McEwan et al., 2011). Given this mechanism, we expect that wetter areas should contain more drought-sensitive species and drier areas should contain more drought-tolerant species. Drought should kill drought-sensitive species, allowing droughttolerant species to become dominant, whereas increased pluvials and decreased drought should cause drought-sensitive species to increase relative to drought-tolerant species and tree densities to increase.

\section{Pattern}

Above average precipitation has occurred in the northeastern US (Peterson et al., 2013) and pluvials have increased since 1970 in the eastern US (Kangas and Brown, 2007). Tree densities also have increased. Red maples (Acer rubrum) and other maple species that are more drought-sensitive than oaks and pines have increased.

\section{Contradictory Evidence}

Because alternative ecosystem states and species can occur within the same climate range, or even outside of climate boundaries (Svenning and Skov, 2004; Cardoso et al., 2018), climate alone poorly predicts the global distribution of species and ecosystems (Bond et al., 2005). Additionally, annual precipitation both above and below the long-term mean occurred during the past century and millennia (Herweijer et al., 2007). Rather than imposing thresholds to determine whether precipitation trends during the 1900s were unique, Hanberry et al. (2018a) analyzed reconstructed PDSI values (Cook et al., 2008) during the last 1000 years to determine if PDSI values differed between the $20^{\text {th }}$ century and other centuries for seven major ecological provinces of the eastern US. Change point detection of shifts in trend means, generalized linear mixed models, and Kolmogorov-Smirnov tests showed that PDSI values 
during the 1900s were not greater than PDSI values during the last millennium for the ecological provinces, similar to results documented by Fye et al. (2003). The PDSI values represent the most comprehensive paleoclimatic reconstruction and do not provide a foundation for substantiation of precipitation change as a clear driver of transitions in eastern forests.

The difference between increasing and decreasing species remains consistent along fire-linked traits, rather than drought tolerance. All fire-tolerant species have decreased. However, drought-tolerant eastern redcedar (Juniperus virginiana) has increased greatly during the past century while droughtsensitive American beech (Fagus grandifolia) has decreased greatly (e.g., Hanberry, 2019). While black oak and northern red oak have decreased, species of the same relative drought tolerance (value of 2.9 to 3.0 on scale of 5; Niinemets and Valladares, 2006) have increased, such as black cherry (Prunus serotina) and sweetgum (Liquidambar styraciflua). Furthermore, species distributions do not reflect that wetter areas should contain more drought-sensitive species; for example, one of the most drought-tolerant species, longleaf pine, dominated the wettest region in the eastern US in the past (Hanberry and Nowacki, 2016).

Pluvials also are not a necessary mechanism for ecosystem transitions through increased tree establishment and forest expansion (e.g., Ziegler et al., 2008; Shuman et al., 2009; Flatley et al., 2013; Rogers and Russell, 2014). Shuman et al. (2009) attributed the transition from open oak forests to closed forests composed of many species in Minnesota to drought, which prevented development of an herbaceous layer for fine fuels, and consequent reduction of fire frequency from 1350 to 1650, rather than pluvials. Therefore, drought alone without an antecedent pluvial in the eastern US has resulted in transitions from open to closed forests and phase shifts to denser tree growth in open ecosystems. In northeastern oak forests, recent drought slowed but did not stop continued expansion by red maple, a species that has increased the most during the past century, excluding planted loblolly pine (Pinus taeda; Lorimer, 1984; Abrams, 1998). Similarly, trees have established in grasslands during drought (McComb and Loomis, 1944; Abrams, 1986). Lastly, even though historical open forests had lower stem density than current closed forests, historical forests contained large diameter old trees and often greater biomass than current closed forests (e.g., Hanberry et al., 2018c), indicating that drought did not limit biomass substantially.

\section{Change in Land Use}

Briefly, due to agreement about the magnitude of effects caused by increased land use, we address land use. Historical land management by Native Americans and later Euro-American settlers relied on the use of fire for different objectives and involved some amount of clearing around settlements (Bromley, 1935; Day, 1953; Pyne, 1982; Hammett, 1992; Brown, 2000). Extensive clearing, intensively from 1850 to 1920, followed by agricultural use and subsequent abandonment resulted in turnover in forest composition and structure during reforestation (Williams, 1989). We expect that forests driven by clearing will have a greater proportion of early successional fast-growing species than historical forests, whereas forests specifically affected by forest management practices will favor certain species disproportionately.

Current forests do contain more early successional species and planted pines than in the past, and forestry practices appear to benefit red maple (Abrams, 1998; Fei and Steiner, 2009; Hanberry et al., 2018c). Current land use typically does not incorporate fire or understory control of trees, which results in increased tree densities and favors fire-sensitive species that are more competitive than fire-tolerant species that expend resources on traits to survive fire (Abrams, 1998; Hammond et al., 2015; Hanberry et al., 2018b). Clearing initially may have favored oak and pine advance regeneration in the understory but fire-sensitive species eventually colonized from firebreaks or by plantings or seed spread by wildlife.

\section{REDUCED AND RECOVERED DEER DENSITIES}

\section{Description}

Ungulates in temperate zones have negative effects on tree regeneration and forest structure, at a threshold equivalent to about 5 to 7 white-tailed deer per $\mathrm{km}^{2}$ (based on $70 \%$ of 433 studies, Ramirez et al., 2018). Exclusion of native white-tailed deer produced positive responses for woody vegetation and no effect on herbaceous vegetation in another meta-analysis (Habeck and Schultz, 2015). Thus, areas with reduced tree recruitment where deer densities are high help explain transition to dense forests in areas with low deer densities. Areas with reduced oak recruitment where deer densities are overabundant may be linked to preferential browsing of oaks compared to other tree genera (McEwan et al., 2011).

\section{Mechanism}

White-tailed deer, like fire, consume and top-kill small diameter woody stems, reducing tree densities. Deer also have preferences for certain species, shifting tree species composition toward less palatable species. We expect that reduced deer densities, due to near elimination of white-tailed deer during the late 1800s and fencing of previously free-ranging pigs and cows (Russell et al., 2001; Coté et al., 2004), would allow increases in tree densities, particularly of tree species preferred by deer (Warren and Hurst, 1981; Latham et al., 2005; Rawinski, 2014). Resumption of browse pressure to the threshold of 5 to 7 white-tailed deer per $\mathrm{km}^{2}$ should reduce tree densities, particularly of tree species preferred by deer.

\section{Pattern}

The last major recruitment of oak and the first recruitment of fire-sensitive tree species coincided with a low point in deer browsing and grazing pressure in the eastern US. Additionally, forests increased in density while deer densities were low. Now that deer densities have increased, McWilliams et al. 
(2018) estimated that $59 \%$ to $79 \%$ of examined forestlands showed moderate or high browse impacts, particularly in oak/hickory (Carya) and maple/beech/birch (Fagus/Betula) forest-type groups.

\section{Contradictory Evidence}

Studies that quantify deer density and impacts on forest regeneration may have a natural bias because they often are conducted in localized areas where deer densities are high. However, the southeastern US generally has the greatest deer densities and yet, relatively few studies that have examined effects of deer on plants. In one example, after five years of deer exclusion during 2000 to 2005, Hanberry et al. (2014) did not detect any significant differences in hundreds of plants in two ecoregions of Mississippi with densities $>20 \mathrm{deer} / \mathrm{km}^{2}$. To remove the bias of local studies, two of us (Hanberry and Abrams, 2019) applied generalized linear mixed models to compare current tree stocking (a metric that indicates how much growing space trees are occupying) with estimated deer densities in 1982 and then again in 1996 (allowing for a lag period before deer effects on understory trees affect growing space), reported by county, for the entire eastern US and 11 ecological provinces. Deer densities during the past decades were not related significantly to current tree stocking for the entire eastern US. Deer may have reduced tree stocking in northern regions of Minnesota, Wisconsin, and Michigan; however, this province had both lower deer densities and greater tree stocking than other provinces. We acknowledge that deer population estimates contain great uncertainty, but even if some reports by county are inaccurate estimates, the totality of estimates indicates general relative trends.

Deer browse preferences fail to explain historical oak and pine forests and conversion to fire-sensitive species. Hanberry and Abrams (2019) also compiled deer browse species preferences by region and compared with trends in tree species composition from historical (1620 to 1900) and current tree surveys. Reports of deer browse preference may be conflicting even within a region; nevertheless, both oak and fire-sensitive species are favored by deer (Warren and Hurst, 1981; Russell et al., 2001; Coté et al., 2004; Latham et al., 2005; Rossell et al., 2005; Rawinski, 2014). Regardless of deer browse preferences, almost all tree species have increased in the eastern US, including northern white-cedar (Thuja occidentalis), despite being a species identified as reduced by deer browsing. Decreasing species include fire-tolerant oak and pine species, which range from preferred to non-preferred browse.

Lastly, current deer populations likely are within range of historical deer populations (Hanberry and Abrams, 2019). Oaks and pines recruited successfully in the past with browsing pressure and recruitment of other tree species and compositional conversion has occurred despite recovery of deer to populations comparable with historical populations. Deer at current high densities do not appear to be able to control great tree densities at landscape scales. Even so, deer remain one of the only restraints on tree regeneration; it may be that some amount of herbivory may help maintain open oak or pine forests only when tree regeneration is limited by fire.

\section{LOSS OF FOUNDATION SPECIES, THE AMERICAN CHESTNUT}

\section{Description}

The functional extinction of the foundation tree species American chestnut due to chestnut blight (Cryphonectria parasitica) is another proposed mechanism for plant community change (McEwan et al., 2011). Foundation vegetation shapes ecosystems and provides critical controls. Loss of foundation tree species results in novel forest ecosystems with altered composition, structure, and function (as exemplified by transition in forests of the eastern United States).

\section{Mechanism}

The loss of American chestnut may have released growing space to fire-sensitive species instead of co-dominant oak species during the early 1900s (McEwan et al., 2011). American chestnut's flammability and lost role in sustaining fire in eastern US ecosystems also was stated in McEwan et al. (2011). In flammability experiments, Kane et al. (2019) indeed found that American chestnut's litter matched or exceeded the flammability of all other eastern oaks and pines (Kane et al., 2019). For the loss of American chestnut to explain forest transitions, the past distribution (large-scale) and dominance (at the patch or stand scale) of American chestnut should approximate the areal extent of transitions.

\section{Pattern}

American chestnut comprised a large proportion of basal area in some forests, particularly in the Appalachians, and in those communities, chestnut became revered as part of American lore, with awareness of chestnuts in cultural memory (Collins et al., 2017). Loss of chestnut was associated with increased maple and other fire-sensitive species (Mackey and Sivec, 1973; McCormick and Platt, 1980). Furthermore, the timing of the loss of American chestnut is synchronous with effective suppression of fire across the landscape.

\section{Contradictory Evidence}

The status of American chestnut as a foundation species for the eastern US appears to be a myth (Collins et al., 2017). Importantly, American chestnut had a limited distribution, generally most abundant in the Appalachian Mountains (Hanberry and Nowacki, 2016), whereas state transitions to closed forests of fire-sensitive species occurred within but also far outside of the range of American chestnut; thus, loss of American chestnut would not affect forest composition and structure across the eastern US. Even where considered dominant, American chestnut comprised $2 \%$ of all trees in the central eastern US and $8 \%$ of all trees where chestnut composition was concentrated in the central Appalachian Mountains; the maximum composition of chestnut was $18 \%$ of all stems in two ecological subsections, where oak composition was $21 \%$ and $65 \%$ (Hanberry and Nowacki, 2016). Loss of chestnut favored many oak species (primarily Q. alba and Q. montana) that formed an association with chestnut (Braun, 1950) and therefore oaks, which comprised 
a foundation genus based on dominance throughout the central eastern United States (Hanberry and Nowacki, 2016), were in the best position to capture the growing space vacated by killed neighboring chestnuts (Keever, 1953; Woods and Shanks, 1959). Much of the growing space gained initially by co-occurring oaks was claimed by fire-sensitive species in the longer term (Mackey and Sivec, 1973).

\section{DISCUSSION}

Prior to European contact, eastern North America was dominated by open forests of savannas and woodlands with surface fire as a frequent disturbance, occasional precipitation increases in space and time, and high deer densities. Since Euro-American settlement, fire has been excluded, regional precipitation has been dynamic, land use changes have increased, native animal populations have fluctuated wildly, and species have become extinct, both actually and functionally. Contemporary eastern ecosystems consist of closed forests with infrequent fires, occasional precipitation increases in space and time, and high deer densities. During early Euro-American settlement, synchronous changes in forest composition and structure, precipitation, and deer populations occurred that superficially appear to be connected. However, expected and observed outcomes do not match at relevant temporal and spatial scales, and thus, fail to provide a foundation to explain forest changes or historical forests. In particular, the American chestnut occurred at a relatively small scale compared to widespread forest transitions, deer dynamics created variable spatiotemporal disturbance, and climate may occur in three broad divisions (i.e., Köppen-Trewartha classification) within the eastern United States, with independent short-term weather and long-term climate changes. Land use and management also vary by region and ownership, but fire exclusion is a national campaign.

The humid climate of the eastern US, despite variation, has supported forested ecosystems for thousands of years. Given this, a change in relative moisture means is unlikely to constitute a primary driver of eastern US forest transitions, particularly because recent pluvials vary in space (e.g., primarily the northeastern US) and time (primarily since the 1970s), which do not match with forest transitions. Climate analyses have not established that the eastern US experienced an unprecedented range of moisture variability during the $20^{\text {th }}$ century (Fye et al., 2003; Kangas and Brown, 2007; Peterson et al., 2013; Hanberry et al., 2018a). Thus, invoking increased moisture availability due to climate change as a driving factor for forest change still requires proof that pluvials of the past hundred years were unusual compared to the past thousands of years that oaks and pine dominated eastern landscapes. Furthermore, historical forests were not composed solely of drought-tolerant species (as beech forests could be locally dominant), which should be the outcome of historically droughtier conditions, while tree species of a wide range of drought tolerance have increased under current conditions. Additionally, trees have increased in density and expanded during drought. Thus, a mechanism other than change in precipitation is needed to explain increased stem density of fire-sensitive tree species.

Comprehensive and consistent changes throughout the eastern US, typically following Euro-American settlement, preclude a primary mechanism of disturbance by wildlife dynamics that are spatiotemporally variable with localized and varying effects. Herbivores are potential drivers of open forest structure, yet current high deer densities are not restoring open oak and pine forests. Oaks and pine recruited successfully in the past with browsing pressure from megaconsumers and firesensitive species, regardless of herbivore browse preferences, currently recruit successfully in oak or pine ecosystems in most areas. Oak and pine regeneration may be limited locally by deer browse where deer are limiting all tree regeneration, but competition from numerous fire-sensitive tree species is a greater overall factor. Removal of tree regeneration via browsing is not an ecological problem in open forests; indeed, similar to browsing, the role of fire is a critical understory disturbance that removes woody vegetation, maintaining dominance by herbaceous plants (Hanberry et al., 2018b).

Fire provides a clear mechanism for filtering tree density and species composition via differential mortality in response to surface fire heating. Its consistent presence on the landscape provides a parsimonious explanation for the historical dominance of open forests composed of fire-tolerant oak and pine species. Fire exclusion is a novel change in the disturbance regime that occurred during the early 1900s and fits the timeline of forest change toward increasingly dense forest structure. Fire exclusion as a primary driver provides a unifying process to explain conversion to fire-sensitive species and transition to dense eastern broadleaf forests following western expansion of settlers and increased human densities (Figure 3; Gleason, 1922; Bromley, 1935; Day, 1953; Neumann, 1985; Abrams, 1992; Lorimer, 1993; Brown, 2000; Brose et al., 2001; Peterson and Reich, 2001; Williams, 2005; Arthur et al., 2012; Hanberry et al., 2018a,b; Stambaugh et al., 2018). Importantly, the transition to closed forests of fire-sensitive species is exacerbated by the resulting positive feedbacks whereby these species further reduce the flammability and abundant establishment of fire-sensitive species, which results in difficulty in applying prescribed burns and removal of fire-sensitive species (Mitchell et al., 2009; Ryan et al., 2013; Stambaugh et al., 2015; Dickinson et al., 2016; Kreye et al., 2018; Babl et al., 2020). Beyond the loss of overstory oak and pine dominance, there are consequences for regional biodiversity with the corresponding losses of a diversity of herbaceous plants and vertebrate and invertebrate animals linked to open ecosystems and their diverse understory now monopolized by trees in the absence of fire (Hanberry and Thompson, 2019). We have provided compelling evidence that exclusion of a keystone process, repetitive fire, is the primary cause of the observed transition in forest structure and composition. Ecosystems and associated species may be extirpated without fire if we make management decisions based on climate or other drivers. Even though fire application only may be possible in a small portion of the eastern US due to a variety of constraints, application of other silvicultural techniques, including thinning and large tree retention, will help maintain and restore open forests. 
While fire exclusion is an issue in the eastern US, it also is a problem associated with transition from open grasslands, savannas, and woodlands to forests worldwide. In North America, there have been widespread transitions from open ponderosa pine ( $P$. ponderosa) or oak ( $Q$. garryana and $Q$. kelloggii) woodlands to closed forests of fire-sensitive tree species (e.g., Bekker and Taylor, 2010; Schriver et al., 2018). Likewise, in Europe, there is an on-going debate about the openness of historical ecosystems and influence of large herbivores (Niklasson et al., 2002; Svenning, 2002; Lindbladh et al., 2003; Hédl et al., 2010; Bobiec et al., 2011; Carmona et al., 2013; Bakker et al., 2016). Tree and shrub encroachment has occurred in the Great Plains grasslands and South America, Africa, Europe, Australia, and Asia (e.g., Eldridge et al., 2012). In tropical zones of the Afrotropics, Neotropics, and Australia, in regions with moderate precipitation, researchers are examining alternative ecosystem states of savannas and closed canopy forests (e.g., Cardoso et al., 2018).

Wherever positive feedbacks maintain alternative ecosystem states, multiple factors interact with fire or fire exclusion. That is, we may re-phrase the 'multiple interacting ecosystem drivers hypothesis' as 'multiple interacting factors feedback hypothesis.' Climate and weather are factors that support or suppress fire. Fire regimes do not occur in very dry climates, where herbaceous vegetation is patchy, or in very wet conditions, which suppress ignition; likewise, fires require antecedent weather that grows and dries vegetation. Continuous presence of overstory trees (i.e., an outcome of land use) and deer herbivory help fire control tree regeneration, and therefore maintain open ecosystems conducive to fire. Conversely, fire breaks such as roads and other impervious surfaces, less flammable structures, crop fields, closed forests, and removal of overstory trees and herbaceous vegetation (i.e., land use and conversion) will prevent fire spread (Ryan et al., 2013).

\section{CONCLUSION}

In this age of the Anthropocene, with ecosystem loss due to land use, climate change, non-native species, over-exploitation of natural resources, and pollution, some may consider historical forests and processes irrelevant. Nonetheless, evaluation of ecosystem processes historically, from before Euro-American settlement, provides an ecological framework that allows a different perspective for ecology and management. Namely,

\section{REFERENCES}

Abadir, E. R., Marschall, J. M., Dey, D. C., and Stambaugh, M. C. (2019). Historical fire regimes in red pine forests of the Adirondack Mountains, New York, USA. Nat. Areas J. 39, 226-236.

Abrams, M. D. (1986). Historical development of gallery forests in northeast Kansas. Vegetatio 65, 29-37. doi: 10.1007/bf0003 2124

Abrams, M. D. (1990). Adaptations and responses to drought in Quercus species of North America. Tree Physiol. 7, 227-238. doi: 10.1093/treephys/7.1-2-3-4.227 Abrams, M. D. (1992). Fire and the development of oak forests. Bioscience 42, 346-353. doi: $10.2307 / 1311781$ fire remains a critical ecological process regardless of shifting baselines or altered ranges of variability in any number of factors. Moreover, open oak or pine forests have withstood thousands of years of climate change, unlike recent forests, and oaks and pines are within the climate envelope of future projected climate (Delcourt and Delcourt, 1987).

Instead of management for closed successional forests, we may consider the alternative option of restoration for open oak or pine forests, using fire as a management tool and application of other silvicultural techniques, including thinning and large tree retention. Instead of concern about deer impacts on forests, we may consider that deer are not consuming enough trees to maintain open forests. Instead of focusing on the influence of precipitation on trees, we may consider that a range of precipitation supports temperate forests, as it does in tropical forests where fire regimes rather than precipitation are considered a key determinant of pyrophilic open forests compared to pyrophobic closed forests (Cardoso et al., 2018). Fire was used more extensively in the past but it is still used effectively today and must be applied in the future to support fire-dependent ecosystems and species. Our review contributes to understanding of transition shifts in eastern forests and helps advance the discussion about mechanisms that drive composition and transitions in ecosystems.

\section{AUTHOR CONTRIBUTIONS}

$\mathrm{BH}$ developed the manuscript and all authors contributed in editing.

\section{FUNDING}

Pennsylvania Agriculture Experiment Station project PEN04658 provided financial support for MAb. MAr's contribution was supported by the United States Department of Agriculture National Institute of Food and Agriculture, McIntireStennis Program under University of Kentucky accession number 1011623.

\section{ACKNOWLEDGMENTS}

We thank reviewers for their contributions to the manuscript.

Abrams, M. D. (1998). The red maple paradox. Bioscience 48, 355-364. doi: $10.2307 / 1313374$

Abrams, M. D., and Nowacki, G. J. (2019). Global change impacts on forest and fire dynamics using paleoecology and tree census data for eastern North America. Ann. For. Sci. 76:8. doi: 10.1007/s13595-018-0790-y

Alexander, H. D., and Arthur, M. A. (2010). Implications of a predicted shift from upland oaks to red maple on forest hydrology and nutrient availability. Can. J. For. Res. 40, 716-726. doi: 10.1139/X10-029

Arthur, M. A., Alexander, H. D., Dey, D. C., Schweitzer, C. J., and Loftis, D. L. (2012). Refining the oak-fire hypothesis for management of oak-dominated forests of the eastern United States. J. For. 110, 257-266. doi: 10.5849/jof. 11-080 
Babl, E., Alexander, H. D., Siegert, C. M., and Willis, J. L. (2020). Could canopy, bark, and leaf litter traits of encroaching non-oak species influence future flammability of upland oak forests? For. Ecol. Manag. 458:117731. doi: 10.1016/ j.foreco.2019.117731

Bakker, E. S., Gill, J. L., Johnson, C. N., Vera, F. W. M., Sandom, C. J., Asner, G. P., et al. (2016). Combining paleo-data and modern exclosure experiments to assess the impact of megafauna extinctions on woody vegetation. Proc. Natl. Acad. Sci. U.S.A. 113, 847-855. doi: 10.1073/pnas. 1502545112

Bekker, M. F., and Taylor, A. H. (2010). Fire disturbance, forest structure, and stand dynamics in montane forests of the southern Cascades, Thousand Lakes Wilderness, California, USA. Ecoscience 17, 59-72. doi: 10.2980/17-1-3247

Bobiec, A., Jaszcz, E., and Wojtunik, K. (2011). Oak (Quercus robur L.) regeneration as a response to natural dynamics of stands in European hemiboreal zone. Eur. J. For. Res. 130, 785-797. doi: 10.1007/s10342-010-0471-3

Bond, W. J., Woodward, F. I., and Midgley, G. F. (2005). The global distribution of ecosystems in a world without fire. New Phytol. 165, 525-538. doi: 10.1111/j. 1469-8137.2004.01252.x

Bowman, D. M., O’Brien, J. A., and Goldammer, J. G. (2013). Pyrogeography and the global quest for sustainable fire management. Annu. Rev. Environ. Resour. 38, 57-80. doi: 10.1146/annurev-environ-082212-134049

Braun, E. L. (1950). Deciduous Forests of Eastern North America. Philadelphia, PA: Blakiston.

Briggs, J. M., Knapp, A. K., Blair, J. M., Heisler, J. L., Hoch, G. A., Lett, M. S., et al. (2005). An ecosystem in transition: causes and consequences of the conversion of mesic grassland to shrubland. Bioscience 55, 243-254.

Bromley, S. W. (1935). The original forest types of southern New England. Ecol. Monogr. 5, 61-89. doi: 10.2307/1943098

Brose, P., Schuler, T., Van Lear, D., and Berst, J. (2001). Bringing fire back: the changing regimes of the Appalachian mixed-oak forests. J. For. 99, 30-35.

Brose, P. H., Dey, D. C., Phillips, R. J., and Waldrop, T. A. (2013). A meta-analysis of the fire-oak hypothesis: does prescribed burning promote oak reproduction in eastern North America? For. Sci. 59, 322-334. doi: 10.5849/forsci.12-039

Brown, H. (2000). Wildland burning by American Indians in Virginia. Fire Manag. Today 60, 29-39.

Brown, J. H. Jr. (1960). The role of fire in altering the species composition of forests in Rhode Island. Ecology 41, 310-316. doi: 10.2307/1930221

Buchanan, M. L., and Hart, J. L. (2012). Canopy disturbance history of old-growth Quercus alba sites in the eastern United States: examination of long-term trends and broad-scale patterns. For. Ecol. Manag. 267, 28-39. doi: 10.1016/j.foreco. 2011.11.034

Cardoso, A. W., Oliveras, I., Abernethy, K. A., Jeffery, K. J., Lehmann, D., Edzang Ndong, J., et al. (2018). Grass species flammability, not biomass, drives changes in fire behaviour at tropical forest-savanna transitions. Front. For. Glob. Change 1:6. doi: 10.3389/ffgc.2018.00006

Carmona, C. P., Azcárate, F. M., Oteros-Rozas, E., González, J. A., and Peco, B. (2013). Assessing the effects of seasonal grazing on holm oak regeneration: implications for the conservation of Mediterranean dehesas. Biol. Conserv. 159, 240-247. doi: 10.1016/j.biocon.2012.11.015

Collins, R. J., Copenheaver, C. A., Kester, M. E., Barker, E. J., and DeBose, K. G. (2017). American chestnut: re-examining the historical attributes of a lost tree. J. For. 116, 68-75.

Cook, E. R., Lall, U., Woodhouse, C. A., and Meko, D. M. (2008). North American Summer PDSI Reconstructions, Version 2a. IGBP PAGES/World Data Center for Paleoclimatology Data Contribution Series \# 2008-046. Boulder CO: NOAA/NGDC Paleoclimatology Program.

Copenhaver-Parry, P. E., Shuman, B. N., and Tinker, D. B. (2017). Toward an improved conceptual understanding of North American tree species distributions. Ecosphere 8:e01853.

Coté, S. D., Rooney, T. P., Tremblay, J., Dussault, C., and Waller, D. M. (2004). Ecological impacts of deer overabundance. Annu. Rev. Ecol. Evol. Syst. 35, 113-147. doi: 10.1146/annurev.ecolsys.35.021103.105725

Day, G. M. (1953). The Indian as an ecological factor in the Northeastern forest. Ecology 34, 329-346. doi: 10.2307/1930900

Delcourt, P. A., and Delcourt, H. R. (1987). Late-Quaternary dynamics of temperate forests: applications of paleoecology to issues of global environmental change. Quat. Sci. Rev. 6, 129-146. doi: 10.1016/0277-3791(87) 90030-8
Dickinson, M. B., Hutchinson, T. F., Dietenberger, M., Matt, F., and Peters, M. P. (2016). Litter species composition and topographic effects on fuels and modeled fire behavior in an oak-hickory forest in the Eastern USA. PLoS One 11:e0159997. doi: 10.1371/journal.pone.0159997

Eldridge, D. J., Maestre, F. T., Maltez-Mouro, S., and Bowker, M. A. (2012). A global database of shrub encroachment effects on ecosystem structure and functioning: ecological Archives E093-234. Ecology 93, 2499-2499. doi: 10. 1890/12-0749.1

Fang, Y., and Jawitz, J. (2018). High-resolution reconstruction of the united states human population distribution, 1790-2010. Scientific Data 5:180067. doi: 10. 1038/sdata.2018.67

Fei, S., and Steiner, K. C. (2009). Rapid capture of growing space by red maple. Can. J. For. Res. 39, 1444-1452. doi: 10.1139/x09-065

Flatley, W. T., Lafon, C. W., Grissino-Mayer, H. D., and LaForest, L. B. (2013). Fire history, related to climate and land use in three southern Appalachian landscapes in the eastern United States. Ecol. Appl. 23, 1250-1266. doi: 10.1890/ 12-1752.1

Fralish, J. S., and McArdle, T. G. (2009). Forest dynamics across three centurylength disturbance regimes in the Illinois Ozark hills. Am. Midland Nat. 162, 418-449. doi: 10.1674/0003-0031-162.2.418

Fuller, J. L., Foster, D. R., McLachlan, J. S., and Drake, N. (1998). Impact of human activity on regional forest composition and dynamics in central New England. Ecosystems 1, 76-95. doi: 10.1007/s100219900007

Fye, F. K., Stahle, D. W., and Cook, E. R. (2003). Paleoclimatic analogs to twentiethcentury moisture regimes across the United States. Bull. Am. Meteorol. Soc. 84, 901-909.

Gilliam, F. S., and Platt, W. J. (1999). Effects of long-term fire exclusion on tree species composition and stand structure in an old-growth Pinus palustris (longleaf pine) forest. Plant Ecol. 140, 15-26. doi: 10.1023/A:10097760 20438

Gleason, H. A. (1922). The vegetational history of the Middle West. Ann. Assoc. Am. Geogr. 12, 39-85. doi: 10.1080/00045602209356938

Guyette, R. P., Stambaugh, M. C., Dey, D. C., and Muzika, R. M. (2012). Predicting fire frequency with chemistry and climate. Ecosystems 15, 322-335. doi: 10 . 1007/s10021-011-9512-0

Habeck, C. W., and Schultz, A. K. (2015). Community-level impacts of white-tailed deer on understorey plants in North American forests: a meta-analysis. $A o B$ Plants 7:lv119. doi: 10.1093/aobpla/plv119

Hammett, J. E. (1992). The shapes of adaptation: historical ecology of anthropogenic landscapes in the southeastern United States. Landscape Ecol. 7, 121-135. doi: 10.1007/bf02418943

Hammond, D. H., Varner, J. M., Kush, J. S., and Fan, Z. (2015). Contrasting sapling bark allocation of five southeastern USA hardwood tree species in a fire-prone ecosystem. Ecosphere 6, 1-13.

Hanberry, B. B. (2019). Trajectory from beech and oak forests to eastern broadleaf forests in Indiana, USA. Ecol. Process. 8:3.

Hanberry, B. B., and Abrams, M. D. (2018). Recognizing loss of open forest ecosystems by tree densification and land use intensification in the Midwestern United States. Reg. Environ. Change 18, 1731-1740. doi: 10.1007/s10113-0181299-5

Hanberry, B. B., and Abrams, M. D. (2019). Does white-tailed deer density affect tree stocking in forests of the Eastern United States? Ecol. Process. 8:30.

Hanberry, B. B., Abrams, M. D., and White, J. D. (2018a). Is increased precipitation during the 20th century statistically or ecologically significant in the eastern US? J. Land Sci. 13, 259-265.

Hanberry, B. B., Bragg, D. C., and Hutchinson, T. F. (2018b). A reconceptualization of open oak and pine ecosystems of eastern North America using a forest structure spectrum. Ecosphere 9:e02431. doi: 10.1002/ecs2.2431

Hanberry, B. B., Coursey, K., and Kush, J. S. (2018c). Structure and composition of historical longleaf pine ecosystems in Mississippi, USA. Hum. Ecol. 46, 241-248. doi: 10.1007/s10745-018-9982-1

Hanberry, B. B., Brzuszek, R. F., Foster, H. T. II, and Schauwecker, T. J. (2019). Recalling open old growth forests in the Southeastern Mixed Forest province of the United States. Écoscience 26, 11-22. doi: 10.1080/11956860.2018.149 9282

Hanberry, B. B., and Fraser, J. S. (2019). Visualizing current and future climate boundaries of the conterminous United States: implications for forests. Forests 10:280. doi: 10.3390/f10030280 
Hanberry, B. B., and Hansen, M. H. (2015). Advancement of tree species across ecotonal borders into non-forested ecosystems. Acta Oecol. 68, 24-36. doi: 10.1016/j.actao.2015.07.002

Hanberry, B. B., and Nowacki, G. J. (2016). Oaks were the foundation genus of the east-central United States. Quat. Sci. Rev. 145, 94-103. doi: 10.1016/j.quascirev. 2016.05.037

Hanberry, B. B., and Thompson, F. R. III (2019). Open forest management for early successional birds. Wildl. Soc. Bull. 43, 141-151. doi: 10.1002/wsb.957

Hanberry, P., Hanberry, B. B., Demarais, S., and Leopold, B. D. (2014). Impact by white-tailed deer on community biodiversity in Mississippi, USA. Plant Ecol. Divers. 7, 541-548. doi: 10.1080/17550874.2013.842615

Hédl, R., Kopeck $l$, M., and Komárek, J. (2010). Half a century of succession in a temperate oakwood: from species-rich community to mesic forest. Div. Distrib. 16, 267-276. doi: 10.1111/j.1472-4642.2010.00 637.x

Herweijer, C., Seager, R., Cook, E. R., and Emile-Geay, J. (2007). North American droughts of the last millennium from a gridded network of tree-ring data. J. Clim. 20, 1353-1376. doi: 10.1175/jcli4042.1

Hutchinson, T. F., Stambaugh, M. C., Marschall, J. M., and Guyette, R. P. (2019). Historical fire in the Appalachian Plateau of Ohio and Kentucky, USA, from remnant yellow pines. Fire Ecol. 15:33.

Iverson, L. R., and Prasad, A. M. (1998). Predicting abundance of 80 tree species following climate change in the eastern United States. Ecol. Monogr. 68, 465485.

Kane, J. M., Varner, J. M., and Saunders, M. R. (2019). Resurrecting the lost flames of American chestnut. Ecosystems 5, 995-1006. doi: 10.1007/s10021-0180318-1

Kangas, R. S., and Brown, T. J. (2007). Characteristics of us drought and pluvials from a high-resolution spatial dataset. Int. J. Climatol. 27, 1303-1325. doi: $10.1002 /$ joc. 1473

Keever, C. (1953). Present composition of some stands of the former oak-chestnut forest in the southern Blue Ridge Mountains. Ecology 34, 44-54. doi: 10.2307/ 1930307

Knorr, W., Kaminski, T., Arneth, A., and Weber, U. (2014). Impact of human population density on fire frequency at the global scale. Biogeosciences 11, 1085-1102. doi: 10.5194/bg-11-1085-2014

Kreye, J. K., Varner, J. M., Hamby, G., and Kane, J. M. (2018). Mesophytic litter dampens flammability in fire-excluded pyrophytic oak-hickory woodlands. Ecosphere 9:e02078.

Kreye, J. K., Varner, J. M., Hiers, J. K., and Mola, J. (2013). Toward a mechanism for eastern North American forest mesophication: the role of litter drying. Ecol. Appl. 23, 1976-1986. doi: 10.1890/13-0503.1

Latham, R. E., Beyea, J., Benner, M., Dunn, C. A., Fajvan, M. A., Freed, R. R., et al. (2005). Managing White-Tailed Deer in Forest Habitat From an Ecosystem Perspective: Pennsylvania Case Study. Harrisburg, PA: Audubon Pennsylvania and Pennsylvania Habitat Alliance.

Liebmann, M. J., Farella, J., Roos, C. I., Stack, A., Martini, S., and Swetnam, T. W. (2016). Native American depopulation, reforestation, and fire regimes in the Southwest United States, 1492-1900 CE. Proc. Natl. Acad. Sci. U.S.A. 113, E696-E704.

Lindbladh, M., Niklasson, M., and Nilsson, S. G. (2003). Long-time record of fire and open canopy in a high biodiversity forest in southeast Sweden. Biol. Conserv. 114, 231-243. doi: 10.1016/s0006-3207(03)00043-0

Lorimer, C. G. (1984). Development of the red maple understory in northeastern oak forests. For. Sci. 30, 3-22.

Lorimer, C. G. (1993). "Causes of the oak regeneration problem," in Oak Regeneration: Serious Problems, Practical Recommendations. Gen. Tech. Report SE-84, eds D. Loftis and C. E. McGee (Washington, DC: USDA Forest Service), 14-39.

Lorimer, C. G. (2001). Historical and ecological roles of disturbance in eastern North American forest: 9,000 years of change. Wildl. Soc. Bull. 29, 425-439.

Mackey, H. E. Jr., and Sivec, N. (1973). The present composition of a former oakchestnut forest in the Allegheny Mountains of western Pennsylvania. Ecology 54, 915-919. doi: 10.2307/1935689

Marschall, J. M., Stambaugh, M. C., Jones, B. C., and Abadir, E. (2019). Spatial variability of historical fires across a red pine-oak landscape, Pennsylvania, USA. Ecosphere 10:e02978.
Matlack, G. R. (2013). Reassessment of the use of fire as a management tool in deciduous forests of eastern North America. Conserv. Biol. 27, 916-926. doi: 10.1111/cobi.12121

McCarthy, B. C., Small, C. J., and Rubino, D. L. (2001). Composition, structure and dynamics of Dysart Woods, an old-growth mixed mesophytic forest of southeastern Ohio. For. Ecol. Manag. 140, 193-213. doi: 10.1016/s03781127(00)00280-2

McComb, A. L., and Loomis, W. E. (1944). Subclimax prairie. Bull. Torrey Botan. Soc. 71, 46-76.

McCormick, J. F., and Platt, R. B. (1980). Recovery of an Appalachian forest following the chestnut blight or Catherine Keever-you were right! Am. Midland Nat. 104, 264-273.

McEwan, R. W., Dyer, J. M., and Pederson, N. (2011). Multiple interacting ecosystem drivers: toward an encompassing hypothesis of oak forest dynamics across eastern North America. Ecography 34, 244-256. doi: 10.1111/j.16000587.2010.06390.x

McWilliams, W. H., Westfall, J. A., Brose, P. H., Dey, D. C., D’Amato, A. W., Dickinson, Y. L., et al. (2018). Subcontinental-Scale Patterns of Large-Ungulate Herbivory and Synoptic Review of Restoration Management Implications for Midwestern and Northeastern Forests. Gen. Tech. Rep. NRS-182. Newtown Square, PA: US Department of Agriculture, Forest Service, Northern Research Station.

Mitchell, R. J., Hiers, J. K., O’Brien, J., and Starr, G. (2009). Ecological forestry in the Southeast: understanding the ecology of fuels. J. For. 107, 391-397.

Neumann, T. W. (1985). Human-wildlife competition and the passenger pigeon: Population growth from system destabilization. Hum. Ecol. 13, 389-410. doi: $10.1007 /$ bf01531152

Niinemets, Ü., and Valladares, F. (2006). Tolerance to shade, drought, and waterlogging of temperate northern hemisphere trees and shrubs. Ecol. Monogr. 76, 521-547. doi: 10.1890/0012-9615(2006)076[0521:ttsdaw]2.0.co;2

Niklasson, M., Lindbladh, M., and Björkman, L. (2002). A long-term record of Quercus decline, logging and fires in a southern Swedish Fagus-Picea forest. J. Veg. Sci. 13, 765-774. doi: 10.1111/j.1654-1103.2002.tb02106.x

Nowacki, G. J., and Abrams, M. D. (2008). The demise of fire and "mesophication" of forests in the eastern United States. Bioscience 58, 123-138. doi: 10.1641/ b580207

Nowacki, G. J., and Abrams, M. D. (2015). Is climate an important driver of postEuropean vegetation change in the Eastern United States? Glob. Change Biol. 21, 314-334. doi: 10.1111/gcb.12663

Palmer, W. C. (1965). Meteorological Drought, Res. Pap. 45. Washington, DC: U.S. Department of Commerce Weather Bureau.

Parshall, T., and Foster, D. R. (2002). Fire on the New England landscape: regional and temporal variation, cultural and environmental controls. J. Biogeogr. 29, 1305-1317. doi: 10.1046/j.1365-2699.2002.00758.x

Pederson, N., D’Amato, A. W., Dyer, J. M., Foster, D. R., Goldblum, D., Hart, J. L., et al. (2015). Climate remains an important driver of post-European vegetation change in the eastern United States. Glob. Change Biol. 21, 2105-2110. doi: $10.1111 /$ gcb. 12779

Peterson, D. W., and Reich, P. B. (2001). Prescribed fire in oak savanna: fire frequency effects on stand structure and dynamics. Ecol. Appl. 11, 914-927. doi: 10.1890/1051-0761(2001)011[0914:pfiosf]2.0.co;2

Peterson, T. C., Heim, R. R. Jr., Hirsch, R., Kaiser, D. P., Brooks, H., Diffenbaugh, N. S., et al. (2013). Monitoring and understanding changes in heat waves, cold waves, floods, and droughts in the United States: State of knowledge. Bull. Am. Meteorol. Soc. 94, 821-834. doi: 10.1175/bams-d-12-00066.1

Pyne, S. J. (1982). Fire primeval. The Sciences 22, 14-20. doi: 10.1002/j.2326-1951. 1982.tb02087.x

Ramirez, J. I., Jansen, P. A., and Poorter, L. (2018). Effects of wild ungulates on the regeneration, structure and functioning of temperate forests: a semiquantitative review. For. Ecol. Manag. 424, 406-419. doi: 10.1016/j.foreco.2018. 05.016

Rawinski, T. J. (2014). White-Tailed Deer in Northeastern Forests: Understanding and Assessing Impacts. Newtown Square, PA: USDA Forest Service, Northeastern Area State and Private Forestry.

Rogers, T. R., and Russell, F. L. (2014). Historical patterns of oak population expansion in the Chautauqua Hills, Kansas. J. Biogeogr. 41, 2105-2114. doi: $10.1111 /$ jbi.12360 
Rossell, C. R. Jr., Gorsira, B., and Patch, S. (2005). Effects of white-tailed deer on vegetation structure and woody seedling composition in three forest types on the Piedmont Plateau. For. Ecol. Manag. 210, 415-424. doi: 10.1016/j.foreco. 2005.02.035

Russell, F. L., Zippin, D. B., and Fowler, N. L. (2001). Effects of white-tailed deer (Odocoileus virginianus) on plants, plant populations and communities: a review. Am. Midland Nat. 146, 1-26. doi: 10.1674/0003-0031(2001)146[0001: eowtdo]2.0.co;2

Ryan, K. C., Knapp, E. E., and Varner, J. M. (2013). Prescribed fire in North American forests and woodlands: history, current practice, and challenges. Front. Ecol. Environ. 11:e15-e24. doi: 10.1890/120329

Schriver, M., Sherriff, R., Varner, J. M., Quinn-Davidson, L., and Valachovic, Y. (2018). Age and stand structure of oak woodlands along a gradient of conifer encroachment in northwestern California. Ecosphere 9:e02446. doi: 10.1002/ ecs 2.2446

Shuman, B., Henderson, A. K., Plank, C., Stefanova, I., and Ziegler, S. S. (2009). Woodland-to-forest transition during prolonged drought in Minnesota after ca. AD 1300. Ecology 90, 2792-2807. doi: 10.1890/08-0985.1

Stambaugh, M. C., Marschall, J. M., Abadir, E. R., Jones, B. C., Brose, P. H., Dey, D. C., et al. (2018). Wave of fire: an anthropogenic signal in historical fire regimes across central Pennsylvania, USA. Ecosphere 9:e02222. doi: 10.1002/ ecs 2.2222

Stambaugh, M. C., Varner, J. M., Noss, R. F., Dey, D. C., Christensen, N. L., Baldwin, R. F., et al. (2015). Clarifying the role of fire in the deciduous forests of eastern North America: reply to matlack. Conserv. Biol. 29, 942-946. doi: 10.1111/cobi. 12473

Svenning, J. (2002). A review of natural vegetation openness in north-western Europe. Biol. Conserv. 104, 133-148. doi: 10.1016/s0006-3207(01)00162-8

Svenning, J. C., and Skov, F. (2004). Limited filling of the potential range in European tree species. Ecol. Lett. 7, 565-573. doi: 10.1111/j.1461-0248.2004. 00614.x

Van Auken, O. W. (2009). Causes and consequences of woody plant encroachment into western North American grasslands. J. Environ. Manag. 90, 2931-2942. doi: 10.1016/j.jenvman.2009.04.023

Varner, J. M., Gordon, D. R., Putz, F. E., and Hiers, J. K. (2005). Restoring fire to long-unburned Pinus palustris ecosystems: novel fire effects and consequences for long-unburned ecosystems. Restor. Ecol. 13, 536-544. doi: 10.1111/j.1526100x.2005.00067.x

Varner, J. M., Arthur, M. A., Clark, S. L., Dey, D. C., Hart, J. L., and Schweitzer, C. J. (2016a). Fire in eastern North American oak ecosystems: filling the gaps. Fire Ecol. 12,1-6. doi: 10.4996/fireecology.1202001
Varner, J. M., Kane, J. M., Hiers, J. K., Kreye, J. K., and Veldman, J. W. (2016b). Suites of fire-adapted traits in the southeastern USA oaks: multiple strategies for persistence. Fire Ecol. 12, 48-64. doi: 10.4996/fireecology.120 2048

Wade, D. D., Brock, B. L., Brose, P. H., Grace, J. B., Hoch, G. A., et al. (2000). "Fire in eastern ecosystems," in Wildland Fire in Ecosystems: Effects of Fire on Flora. Gen. Tech.Rep. RMRS-42, eds J. K. Brown and J. K. Smith (Ogden, UT: U.S. Department of Agriculture, Forest Service, Rocky Mountain Research Station), 53-96.

Warren, R. C., and Hurst, G. A. (1981). Ratings of Plants in Pine Plantations as white-Tailed Deer Food. Starkville, MS: Mississippi Agricultural Forest Experiment Station.

Whitney, G. G., and DeCant, J. P. (2003). Physical and historical determinants of the pre- and post-settlement forests of northwestern Pennsylvania. Can. J. For. Res. 1697, 1683-1697. doi: 10.1139/ x03-079

Williams, G. W. (2005). References on the American Indian use of Fire in Ecosystems. Available online at: https://www.nrcs.usda.gov/Internet/FSE_DOCUMENTS/ nrcs144p2_051334.pdf (accessed March 26, 2019).

Williams, M. (1989). Americans and Their Forests. New York, NY: Cambridge University Press.

Woods, F. W., and Shanks, R. E. (1959). Natural replacement of chestnut by other species in the great smoky mountains National Park. Ecology 40, 349-361. doi: $10.2307 / 1929751$

Ziegler, S. S., Larson, E. R., Rauchfuss, J., and Elliott, G. P. (2008). Tree establishment during dry spells at an oak savanna in Minnesota. Tree Ring Res. 64, 47-55.

Conflict of Interest: The authors declare that the research was conducted in the absence of any commercial or financial relationships that could be construed as a potential conflict of interest.

The reviewer JO'B declared a past collaboration with one of the authors JV to the handling Editor.

Copyright (c) 2020 Hanberry, Abrams, Arthur and Varner. This is an open-access article distributed under the terms of the Creative Commons Attribution License (CC BY). The use, distribution or reproduction in other forums is permitted, provided the original author(s) and the copyright owner(s) are credited and that the original publication in this journal is cited, in accordance with accepted academic practice. No use, distribution or reproduction is permitted which does not comply with these terms. 